\title{
FEATURES OF EDUCATIONAL ACTIVITIES OF STUDENTS IN TECHNICAL UNIVERSITIES OF RUSSIA
}

\author{
Bogdan Ershov', Svetlana Solovieva ${ }^{2}$, Sergey Shkarubo ${ }^{3}$, Irina Kolobova ${ }^{4}$ \\ ${ }^{1}$ Doctor of Historical Sciences, Professor, Voronezh State Technical University, 20 years of \\ October street, 84,Voronezh, Russia, E-mail: bogdan.ershov@yandex.ru \\ ${ }^{2}$ Senior Lecturer, Voronezh State Technical University, 20 years of October street, 84,Voronezh, \\ Russia, E-mail: d18sveta@mail.ru \\ ${ }^{3}$ Candidate of Philosophy, Associate Professor, Department of History, Moscow Aviation Institute \\ (National Research University), Volokolamskoe shosse, 4, Moscow, Russia \\ E-mail: serge_philosof@mail.ru \\ ${ }^{4}$ Senior Lecturer, Voronezh State Technical University, 20 years of October street, 84, Voronezh, \\ Russia, E-mail: rybirina@rambler.ru
}

\begin{abstract}
The article considers the pedagogical heritage of the Russian Orthodox Church, which contains an inexhaustible educational potential that is not subject to ideological fluctuations, since it is based on unchanging values. In Orthodoxy and the harsh Russian nature lie the origins of the Russian soul and the keys to its understanding. In Orthodoxy, Russian military commanders and soldiers, writers and artists, scientists, naturalists, doctors, devotees of piety were brought up.

At present, the Orthodox Church can offer a holistic, positive educational system that has been tested for ten centuries. The interaction of the state and the Russian Orthodox Church is a unique phenomenon of joint, complementary resources to address critical issues of a moral nature.
\end{abstract}

Keywords: church, education, science, society, state.

\section{INTRODUCTION}

The improvement of modern engineering education dictates the orientation of universities on key elements of the preparation of professional disciplines, the modern teaching of which does not meet the changing socioeconomic conditions and requirements. If previously the professional training of an engineer was associated with the traditional study of the cycle of professional disciplines as a whole, then at present the student should be trained as a competitive worker who knows production. Since private improvements do not solve the problem, it is impossible to optimize training in professional disciplines (to coordinate the interaction of subjects of engineer training) without specifying the methodological basis of such activities. 
In order to optimize the training of technical university students in professional disciplines and to get competent personnel from industrial and research enterprises, it is necessary to focus not only on the requirements of educational standards, but also on the individual requirements for graduates that employers make. Statistical data of the last decade are presented in the works of T.V. Andryushina, O.B. Bolbat, N.I. Bulaeva A.B. Chudinova allowed to conclude that the training of specialists in the modern system of higher professional education does not always satisfy employers.

Graduates of engineering universities do not have sufficient training for effective work, are poorly adapted to new business conditions, cannot quickly reorient themselves to the rhythm and conditions of enterprises, cannot retrain and predict the development of scientific and technical areas in which they will have to work.

Therefore, in the formation and development of future engineers of professional competencies of various types and levels, it becomes necessary to determine the criteria for optimizing training in professional disciplines, not only taking into account the requirements of existing educational standards, but also the requirements of the enterprise.

\section{METHODOLOGY}

Methods of theoretical analysis were used at all stages of the study, starting with the study of literary sources. Methods of pedagogical diagnostics were used at the last stage to process the results of experimental work. The modeling method was used to explain and reproduce the studied object - the pedagogical process of professional preparation of students for innovative activity in the following logical sequence: model of the learning process - model of a specialist - model of the content of training.

Methods of analysis of instructions, qualification characteristics, state educational standards and other documents were used to study the nature and content of the activities of specialists, to clarify the requirements for their knowledge and skills. The study of pedagogical experience was carried out in order to familiarize ourselves with the practice of the work of Russian and foreign universities in modern professional training of students. For the purpose of experimental verification of the designed pedagogical process, experimental work was carried out.

\section{DISCUSSION}

The historiographic basis of the article is the theory of a systematic approach to the content of education (B.G. Ananyev, L.V. Zankov, V.V. Davydov, Yu.A. Konarzhevsky, N.V. Kuzmina, V.N. Sadovsky, G.P. Shchedrovitsky, VA Yakunin), the theory of pedagogical integration (AP Belyaeva, BC Lednev, I.Ya. Lerner, MI Makhmutov, Yu.S. Tyunnikov, NK Chapaev, V.V. Schipanov, A.N. Yarygin), the concept of modeling and designing the pedagogical process (S.I. Arkhangelsky, V. Bezrukova, V. P. Bespalko, M. V. Klarin, V. A. Slastenin, N. F. Talyzina, Yu.K. Chernova, P.A. Yutsavichene), the theory of creative development and selfdevelopment (V.I. Andreev, M.A. Galaguzova, I.A. Zimnaya, V.V. Kraevsky, T.I. Shamova, V.I.Schegol), the theory of selection of the content of education (Yu.K. Babansky, S.Ya. Batyshev, G.L. Ilyin, G.P. Kornev, Yu.A. Kustov, V.V. Multanovsky, V.G. Razumovsky, M.N. Skatkin), development qualimetry methodology person (Yu.P. Adler, V.M. Polonsky, V.M. Sokolov, A.I. Subetto, N.A. Selezneva, Yu.G. Tatur, V.D. Shadrikov), theory of motivation (A. A. Verbitsky, L.S. Vygotsky, O.S. Grebenyuk, P.Ya. Halperin, A.N. Leont'ev, A. Maslow, V. Piaget, S.L. Rubinstein).

The implementation of the problem is based on the methodological approaches of domestic and foreign authors to innovative processes in the education system and the practice of teaching scientific and technical creativity (G.S. Altshuller, G.Ya. Bush, A.V. Gordeev, U. Gordon, M.V. Kazakov, Yu.V. Kazakov, Z.F. Mazur, M. Tring, F. Zwicky and others), on innovative approaches to the training of teachers of scientific and technical creativity (O.L.Berak, Yu.A. Karpova, V. . I. Liaudis, A.I. Polovinkin and others), on the modern approach to strategic and innovative management (I. Ansoff, P.N. Zavlin, S.D. llyenkova, A.K. Kazantsev, B. Karlov, L.E. Mindeli, A.A. Thomson, A.J. Strickland, R.A. Fathutdinov, etc.).

\section{RESULTS}

An analysis of the existing pedagogical literature on this issue led to the conclusion that the optimization of education is a category of didactics that shows the possibility of improving the quality of training of graduates of engineering universities by improving the content, forms, methods and conditions of rational training of engineering personnel. In addition, in the course of the study it was found that optimization allows for the implementation of coordination functions of interactions of subjects interested in quality, dynamic transformations of the subjects themselves, the integrity of the training process through the unity of technological, dialogical and motivational structural components. 
Since modern real engineering activity is associated with the issues of addressing a specialist to the interests of a person who is a consumer of the results of engineering work, professional training is associated with the need to solve the problems of a more civilized and wise use of scientific and technical potential, social and environmental aspects of economic development. Therefore, when optimizing training in professional disciplines, an organic combination of professional / special and general cultural education is necessary. Moreover, the purpose of training is not only the formation of professional qualifications, but the development of the necessary professional and personal qualities of a future engineer. At the same time, our study reflects that optimizing the process of professional training of engineers, teachers should take into account current trends in the humanization of engineering education, i.e. when studying a specific discipline of a professional / general professional nature, it is necessary to form an understanding of the actual actual professional reality and the attitude of the students adequate to it, as well as to develop the students' suprasituational activity, which is designed to help in the prevention of various professional deformations. At the same time, humanization was considered as a mechanism that allows you to develop a person as a professional through continuous transformation and qualitative change in subjective experience.

\section{CONCLUSION}

By optimizing the learning process in line with the competency-based approach, the leading subject, the teacher, must make a rational choice of training and educational tools to achieve the required (and sometimes provided) competencies of a qualifying and professional-personal nature.

For the formation of quick and effective psychological adaptation of students at the enterprise and the targeted development of the personality of the future professional in the process of training students, it is necessary to use individualized systems, depending on their initial production experience and the initial competencies of a qualifying and personal nature.

\section{REFERENCE LIST}

Clarin M. V. (1995) Innovations in world pedagogy. Riga. SPC "Experiment". 176 p. (in Russ).

Ershov B.A. (2010) The Russian Orthodox Church and secular power in the Voronezh province in the XIX early XX centuries. GOU VPO "Voronezh State Technical University". Voronezh. 167 p. (in Russ).

Ershov B.A. (2010) The system of spiritual education in Voronezh province in the 19th century. Education and Society. №. 5 (64). Pp. 105-108. (in Russ).

Ershov B.A., Fursov V.N. (2018) The Russian Church in the State Mechanism of Russia. Bulletin SocialEconomic and Humanitarian Research. № 1. Pp. 32-37.(in Engl).

Ershov B.A., Perevozchikova L.S., Romanova E.V. (2019) Globalization and Intensification of Spiritual Values in Russia in the Philosophical Aspect. 6th International Conference on Education and Social Sciences Abstracts \& Proceedings. Pp. 208-212. (in Engl).

Ershov B.A., Perevozchikova L.S., Romanova E.V., Ashmarov I.A. (2019) The Concept of Spirituality in Social Philosophy. Smart Innovation, Systems and Technologies. T. 139. Pp. 688-694. (in Engl).

Fromm, E. (1992) The Soul of man. 432 p. (in Russ).

Isaev E. (2012) Introduction to the anthropology of education. monograph. Birobidzhan: publishing house of Sholom Aleichem vocational school. 215 p. (in Russ).

Kozyrev F. N. (2006) Religion as a subject of study: the experience of constructing a phenomenological model. Bulletin of Orenburg state University. № 2 (52). Vol. 1: Humanities. Pp. 57-66. (in Russ).

Kuzmina N. V. (1970) Problems of professional training of specialists in higher education institutions. Problems of selection and professional training of specialists in higher education institutions. Pp. 4761. (in Russ).

Laudis V. J. (1998) a New paradigm of pedagogical psychology and practice of innovative education. Bulletin of the Moscow University. Ser. 14. Psychology. №. 2. Pp. 88-97. (in Russ). 
Novikov D. A. (2007) Project Management: organizational mechanisms. 140 p. (in Russ).

Okolelova E.Yu. (2006) Sustainability of economic processes and assessment of their predictability. Bulletin of Tula State University. Series: Construction, architecture and restoration. Pp. 146-151. (in Russ).

Perevozchikova L.S., Ershov B.A., Ashmarov I.A., Volkova E.A. (2017) Role of Russian Orthodox Church in life of peasants in Russia in XIX-the beginning of the XX-th centuries Bylye Gody. Russian historical journal. №. 43 (1). Pp. 121-128. (in Engl).

Popov A. (1995) Genesis of management and management. Higher education in Russia. №. 2. Pp. 64-71. (in Russ).

Romanova E.V., Perevozchikova L.S., Ershov B.A. (2017) The Lifestyle of the Human Being in the Information Society. 3rd International Conference on Advances in Education and Social Sciences Proceedings of ADVED Pp. 950-954. (in Engl).

Ryzhkova V. I. (2003) Differentiation of education as an important factor in the development of students' cognitive interest. Head Teacher. № 8. Pp. 58-63. (in Russ).

Shishov S. E. (1999) The concept of competence in the context of the quality of education. Standards and monitoring in education. № 2. Pp. 30-34. (in Russ).

Smirnov I. P. (2002) Man. Education. Profession. Personality. Monograph. 500 p. (in Russ).

Talyzina N. F. (1987) Ways to develop a specialist profile. SSU. 173 p. (in Russ).

Vygotsky L. S. (1956) History of the development of higher mental functions M. Pedagogy, Vol. 3. 368 p. (in Russ). 